\title{
WSPÓŁCZESNE MODERNIZACJE ZABYTKOWYCH ZESPOŁÓW KOSZAROWYCH - ANALIZA WYBRANYCH REALIZACJI NA TERENIE POLSKI
}

\author{
Dorota Gawryluk \\ Wydział Budownictwa i Inżynierii Środowiska, Politechnika Białostocka \\ Faculty of Civil and Environmental Engineering, Białystok University of Technology \\ e-mail:d.gawryluk@pb.edu.pl
}

\begin{abstract}
Streszczenie. W artykule zaprezentowano przykłady zrealizowanych w Polsce modernizacji zabytkowych zespołów koszarowych. Zaprezentowano przykłady dawnych zespołów powojskowych, których funkcja została współcześnie zmieniona. Podjęto próbę uporządkowania w/w estetycznych działań projektowych, prowadzonych w ostatnich dekadach na dwie zasadnicze grupy: inspirowanych kontekstem historycznym i wpisujących się weń oraz wybijających się z zabytkowego tła nowoczesną formą akcentów i detali.
\end{abstract}

Słowa kluczowe: zabytkowe koszary, modernizacja, rewaloryzacja

\section{WSTĘP}

Częścią spuścizny okresu zaborów na terenach polskich są licznie zachowane zespoły koszarowe ${ }^{1}$.

W XIX wieku wznoszone zazwyczaj na obrzeżach miast, na przestrzeni lat zostały przez te ośrodki wchłonięte i współcześnie często stanowią ich wewnętrzne dzielnice. Kompleksy pokoszarowe stanowią zwarte zespoły urbanistyczne dzięki czemu są czytelne w strukturze przestrzennej ośrodków i podobnie jak antyczne obozy rzymskie „,castrum romanum” świadczą o minionej epoce $\mathrm{w}$ dziejach miast ${ }^{2}$. Współczesne losy zabytkowych koszar są bardzo różne od świadomego zniszczenia (budynek koszarowy przy Łazienkach Królewskich w Warszawie, 2011), do rewitalizacji mającej na celu stworzenie z koszar nowego symbolu miasta (Poznań, Gdańsk Wrzeszcz, Ełk). Dotyczą całego spektrum działań od zniszczenia, do tworzenia nowej jakości przestrzeni honorującej historię miejsca. Realizacje ostatnich dekad dotyczące modernizacji zabytkowych zespołów koszarowych na terenie Polski można podzielić na dwie grupy: ze względu na zmianę funkcji oraz na zmianę bryły obiektów. Historia trzech zaborów czytelna w różnych formach architektonicznych zabytkowych zespołów, nie predestynuje żadnego

1 Król A., 1936. Budownictwo wojskowe 1918-1935. Historia, przepisy, zasady, normy., t. 1, Zakłady Drukarskie Galewski i Dau w Warszawie, Warszawa;

Holewiński M.,1996. Atlas Twierdzy Kraków. Koszary Arcyksięcia Rudolfa, seria I, tom 6, Kraków;

Urbaniak M., 2012. Leszczyńskie koszary z lat 1901-1905 na planach budowlanych Archiwum Państwowego w Lesznie, Leszno;

Wiraszka M., 2008. Rozwój przestrzenny i zabudowa miast Guberni Podolskiej w czasach Imperium Rosyjskiego, Neriton, Warszawa;

Kalina T., 2014. Wojskowe nieruchomości zabytkowe znane i nieznane, Biuro Infrastruktury Specjalnej, Wojskowe Centrum Edukacji Obywatelskiej, Warszawa;

Paszkiewicz P., 1999.W stużbie Imperium Rosyjskiego 1721-1917, Instytut Sztuki PAN, Warszawa.

2 Benevolo L.,1988. The history of the city, The MIT Press, Cambridge Massachusetts;

Ostrowski W., 2001. Wprowadzenie do historii budowy miast. Ludzie i środowisko, OWPW Warszawa. 
rodzaju do szczególnej nowej funkcji . Należy podkreślić, że mimo, iż obiekty są związane $\mathrm{z}$ trudnym okresem w dziejach Polski (były symbolicznym manifestem władzy zaborców), to współcześnie w większości wypadków nie są odczytywane pejoratywnie. Wpisały się w krajobraz tożsamości poszczególnych regionów Polski oraz dziedzictwa zaakceptowanego przez społeczeństwo.

\section{MODERNIZACJA FUNKCJONALNA}

Skala zespołów po dawnych koszarach predestynuje je do rewaloryzacji i przeznaczenia na obiekty o bogatych programach funkcjonalnych. W 2007 r. ukończono adaptację i przebudowę koszar przy ul. Ułańskiej, Wojskowej i Wyspiańskiego w Poznaniu (dawne koszary 15 Pułku Ułanów Poznańskich). Arch. Sławomir Rosolski, odwołując się do nadrzędności tożsamości miejsca, w procesie projektowania tego kompleksu, wykorzystał koncepcje zagadnień odwrotnych w celu wkomponowania nowej funkcji w zastaną historyczną formę. City Park jego autorstwa to założenie urbanistyczne (apartamenty, biura, hotel, galeria handlowa, lokale usługowe). Realizacja została wyróżniona nagrodą Jana Baptysty Quadro (2009). W 2009 r. biuro CDF Architekci wykonało projekt rewitalizacji obszaru po dawnej fabryce Modena, która znajdowała się na terenie kolejnego zespołu zabytkowych koszar w Poznaniu. Projekt Modena Park mieści obiekty o funkcji mieszkalnej, handlowej, usługowej i biurowej. Na uwagę zasługuje fakt, iż autorzy programowo połączyli obszar nowego osiedla z tkanką miasta, poprzez sieć przejść dostępnych dla wszystkich, nie tylko dla mieszkańców modernizowanych budynków. ,, Scalenie w spójny kompleks historycznych zabudowań, starego drzewostanu oraz wspótczesnej architektury stworzy unikalna część miasta" ${ }^{5}$ W Olsztynie w latach 2006-2014 zrewitalizowano wg projektu architektów z pracowni Dżus GK Architekci dziewiętnastowieczny zespół powojskowy nadając mu jednocześnie nazwę Koszary Park. W dawnych koszarach artylerii powstały mieszkania oraz powierzchnie przeznaczone na biura, handel i usługi ${ }^{6}$. W gdańskim Wrzeszczu prowadzona jest obecnie, przez firmę Hossa, inwestycja obejmująca ponad 20 ha powierzchni po dawnych koszarach Czarnych Huzarów. Projekt jest dziełem architektów z Pracowni Projektowej GI Hossy kierowanej przez Marcina Woyciechowskiego ${ }^{7}$. Realizacja przebiega etapami (inwestor wykupił teren w 2005, pierwsze budynki oddano do użytkowania w 2012 r.). Zabudowa zabytkowa została uzupełniona o liczne nowe obiekty. Bogaty program funkcjonalny uzupełnia zabudowę mieszkaniową o biura, usługi, handel oraz obiekty kultury. Ideą projektantów jest, aby dzielnica była przystosowana głównie do ruchu pieszego.

Politechnika Krakowska od kilkudziesięciu lat funkcjonuje w dawnych koszarach Arcyksięcia Rudolfa znajdujących się przy ul. Warszawskiej w Krakowie. Kolejne obiekty uczelni

3 Bętkowski R., 2011.Dragoni z Olsztyna. Dzieje formacji i koszar, Imago Mundi, Olsztyn;

Bogdanowski J., 1996. Architektura obronna w krajobrazie Polski, Wydawnictwo Naukowe PWN, Warszawa-Kraków;

Król A., 1936. Budownictwo wojskowe 1918-1935. Historia, przepisy, zasady, normy., t. 1, Zakłady Drukarskie Galewski i Dau w Warszawie, Warszawa;

Holewiński M., 1996. Atlas Twierdzy Kraków. Koszary Arcyksięcia Rudolfa, seria I, tom 6, Kraków;

Kowalski T., 2013.W Sierpcu za cara. Śladami rosyjskiego garnizonu, Towarzystwo Przyjaciół Ziemi Sierpeckiej, Sierpc.

4 Rosolski S., 2014.City Park- tożsamość miejsca w mieście $w$ aspekcie zagadnień odwrotnych, Zeszyty Naukowe Politechniki Poznańskiej. Architektura i Urbanistyka, 31, s. 19-30.

5 cdf.net.pl/modena-park-w-poznaniu.html, dostęp 5.05.2015.

6 www.bryla.pl/bryla/1,85301,17557888,Olsztyn_dawne_koszary_wojskowe, dostęp: 5.05.2015.

7 trojmiasto.gazeta.pl/trojmiasto/1,35636,7151329,Artysci_chca_zamienic_dawne_koszary_w_sale_wystaw.html, dostęp: 3.04.2015. 
są sukcesywnie poddawane modernizacji ${ }^{8}$. Na uwagę zasługują budowle tj. Kotłownia, Areszt, czy oddana do użytku w 2014 r. Działownia, w których poza dbałością o utrzymanie czytelności zabytkowej formy, zachowano także dawne nazwy w celu podkreślenia historycznego charakteru miejsca (Ryc. 1). Budynki poszczególnych wydziałów (Wydział Inżynierii Lądowej, Wydział Inżynierii Elektrycznej i Komputerowej, Wydział Architektury) są poddawane modernizacji (nadbudowane piętra, dobudowane klatki schodowe, piony wind) (Ryc. 2). Warte podkreślenia są także zabiegi uczelni w celu uporządkowania zieleni i zachowania czytelności głównego placu alarmowego dawnych koszar - obecnie wewnętrznego dziedzińca ze skwerem. Detale urbanistyczne tj. bramy i ogrodzenia, tablice informacyjne, popiersie Tadeusza Kościuszki usytuowane na głównej osi kompozycyjnej założenia przypominają dawną wojskową historię miejsca (Ryc. 3 i 4$)^{9}$.

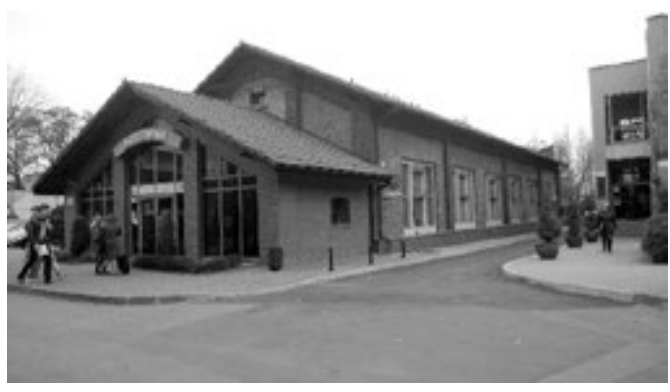

Ryc. 1. Politechnika Krakowska - Kotłownia. Źródło: D. Gawryluk

Fig. 1. Kraków University of Technology boiler house. Source: D. Gawryluk

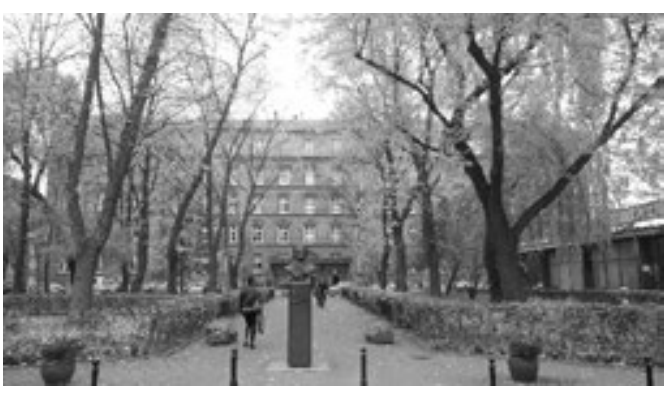

Ryc. 3. Politechnika Krakowska - popiersie Tadeusza Kościuszki na tle Wydziału Arch. Źródło: D. Gawryluk

Fig. 3. Kraków University of Technology - Tadeusz

Kosciuszko's sculpture bust Source: D. Gawryluk

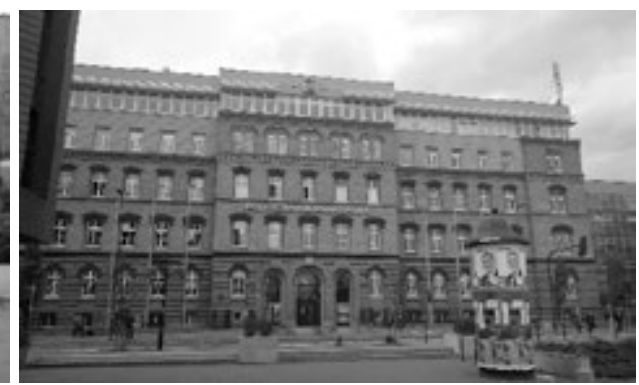

Ryc. 2. Politechnika Krakowska - budynek główny. Źródło: D. Gawryluk

Fig. 2. Kraków University of Technology Main building. Source: D. Gawryluk

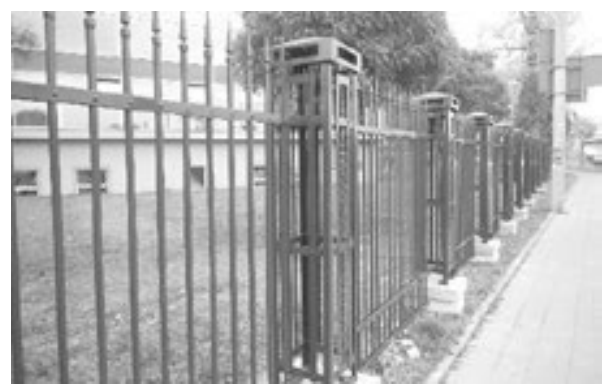

Ryc. 3. Politechnika Krakowska - detal ogrodzenia Źródło: D. Gawryluk

Fig. 3. Kraków University of Technology Detail of the fence Source: D. Gawryluk

Wydział Nauk Społecznych Uniwersytetu Wrocławskiego (Wrocław, ul. Koszarowa) także funkcjonuje w dawnych koszarach. Charakterystyczne detale wejść do poszczególnych budynków świadczą o współczesnej ich modernizacji. W Tarnowie dawne tzw. Górne Koszary zostały przystosowane do potrzeb Państwowej Wyższej Szkoły Zawodowej ${ }^{10}$. Konkurs na koncepcję ich zagospodarowania wygrał w 1995 r. zespół architektów krakowskich w składzie: Małgorzata

8 Holewiński M., 1996. Atlas Twierdzy Kraków. Koszary Arcyksięcia Rudolfa, seria I, tom 6, Kraków, s. 1-2.

9 Wielgus K. i in., 2010. Koncepcja zagospodarowania terenu Politechniki Krakowskiej przy ulicy Warszawskiejna Centrum Muzealno-Edukacyjne, Kraków, maszynopis opisu do w/w koncepcji udostępniony przez autora.

10 Krupiński A., 2000. Dzieje i architektura tzw. Górnych Koszar obecnej siedziby Państwowej Wyższej Szkoty Zawodowej w Tarnowie, Tarnów. 
i Marcin Włodarczykowie, Janusz Sepioł, Katarzyna Oleksińska i Wojciech Piektun. Zespół pod kierownictwem prof. Andrzeja Kadłuczki opracował studium historyczno-architektoniczne i stało się ono podstawą wykonania projektu realizacyjnego restauracji i adaptacji dawnych koszar, który następnie został przygotowany pod kierownictwem arch. Janusza Dziduszki przez Wielobranżowe Biuro Projektów ${ }^{11}$. Na potrzeby uczelni zostały zaadaptowane także dawne koszary carskie znajdujące się przy ul. Batorego w Skierniewicach. Inwestycja została wyróżniona, jako „Modernizacja Roku 2011” w konkursie, któremu patronowały m.in. Ministerstwo Infrastruktury i Ministerstwo Edukacji Narodowej ${ }^{12}$. W pocarskich koszarach swoje miejsce znalazł kampus Państwowej Wyższej Szkoły Zawodowej w Skierniewicach ${ }^{13}$. Funkcja uczelni została wpisana w zabytkowy kompleks zgodnie z zasadą honorowania wartości historycznych miejsca. Wartościowym przykładem obiektu pokoszarowego, obszaru zaboru austriackiego, przystosowanego do funkcji wystawienniczej jest Muzeum Armii Krajowej w Krakowie funkcjonujące w zrewaloryzowanym obiekcie od 2011 r., zrealizowane według projektu pracowni Air Jurkowscy Ar-

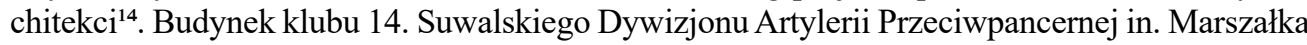
Józefa Piłsudskiego w Suwałkach w pierwszej dekadzie XXI w. został odrestaurowany i przystosowany do celów m.in. wystawienniczych ${ }^{15}$. „Stałą wystawę muzeum historii i tradycji żołnierzy Suwalszczyzny" eksponowaną wewnątrz budynku, uzupełnia ekspozycja dział prezentowana na działce klubu.

„Brama Mazur” to zrewitalizowany obszar po dziewiętnastowiecznych pruskich koszarach położonych w centrum Ełku. Biuro architektoniczne CDF w 2011 r. opracowało dla tej lokalizacji dokumentację obiektów centrum handlowego, kina, restauracji połączonych przestrzeniami publicznymi placów ${ }^{16}$. Zgodnie z koncepcją projektantów zabytkowe budynki pokoszarowe nadają indywidualny charakter projektowanej przestrzeni uzupełnionej o współczesną architekturę. Zrewitalizowany zespół obiektów, jako symbol regionu, funkcjonuje od $2014 \mathrm{r}$. W Ostródzie tzw. „Białe Koszary” wzniesione w latach 1913-1927, po II wojnie światowej aż do 2001 roku były użytkowane przez wojsko polskie. Po renowacji (2009-2013) są siedzibą Sądu Rejonowego i Prokuratury oraz Starostwa Powiatowego, a także Centrum Użyteczności Publicznej, w którym jest miejsce dla 50 organizacji pozarządowych ${ }^{17}$. W Świnoujściu obok urzędów administracji publicznej (po rewaloryzacji), w zespole dawnych koszar funkcjonują także miejski ośrodek kultury z teatrem (po rewaloryzacji), szkoła, część budynków pełni funkcję mieszkalną.

\section{MODERNIZACJA FORMALNA}

Wśród polskich przykładów współcześnie rewaloryzowanych obiektów koszarowych, podobnie jak w zagranicznych realizacjach, możemy wyróżnić dwa podejścia ze względu na traktowanie historycznej wartości obiektów. W pierwszej grupie mieszczą się obiekty, w których działania nową formą kontrastują z zabytkowym tłem. Drugą grupę stanowią realizacje, w których wartość historyczna obiektów jest nadrzędna, a nowe wtrącenia nie konkurują z zabytkową formą budowli. Modernizacja formy i przestrzeni koszar jest szczególnie czytelna

11 Ibidem, s. 18-19.

$12 \mathrm{http}: / /$ leszektrebski.pl/?project=dawne-koszary-carskie, dostęp: 8.05.2014.

$13 \mathrm{http} / / /$ www.pwsz.skierniewice.pl/pl-pl/galeria/campus/budynki.aspx, dostęp: 20.10.2015.

14 Wielgus K., Żaba T., Springwald R., 2013.Muzeum Armii Krajowej i Politechnika Krakowska - dobre sąsiedztwo:Ku czci żolnierzy Polski Podziemnej, [w:] Nasza Politechnika, 2, s. 3-8.

15 Kalina T., 2014. Wojskowe nieruchomości zabytkowe znane i nieznane, Biuro Infrastruktury Specjalnej, Wojskowe Centrum Edukacji Obywatelskiej, Warszawa, s. 118-123.

16 cdf.net.pl/galeria-handlowa-brama-mazur-w-elku.html, dostęp: 5.05.2015.

17 Iwaniec M., 2013. „Białe Koszary”w Ostródzie, Renowacje i Zabytki 4, s. 148-152. 
w nowych zespołach z dominującą funkcją mieszkalną, realizowanych w Gdańsku Wrzeszczu i Poznaniu (City Park, Modena Park). W skali urbanistycznej, wybrane nowe obiekty stanowią silne akcenty, wyróżniające się w regularnej dawnej strukturze. W Ełku skala zabytkowych budynków jest kontynuowana w zespole „Bramy Mazur” wysokością, tektoniką elewacji oraz kolorystyką prostopadłościennych form centrum handlowego. W skali obiektów czytelne są współczesne wtrącenia w postaci detali skontrastowanych $\mathrm{z}$ historycznym tłem, np. nadbudowana wyoblonym, przeszklonym przekryciem, kondygnacja z basenem w korpusie głównego budynku kompleksu, czy przeszklony łącznik budynków przerzucony nad ulicą w City Park w Poznaniu. W Suwałkach w dawnych carskich koszarach przy ul. Dwernickiego, jeden z budynków został zaadaptowany na hotel „Loft 1898” wg projektu Atelier ZETTA z Białegostoku. Obiekt został otwarty w 2015 r. (Ryc.5.). Do historycznej budowli dobudowano od frontu współczesne skrzydło, a na korpusie hotelu zrealizowano detale akcentujące główne wejście i wybrane narożniki. Pomimo tych działań wartości historyczne obiektu są nadal czytelne.

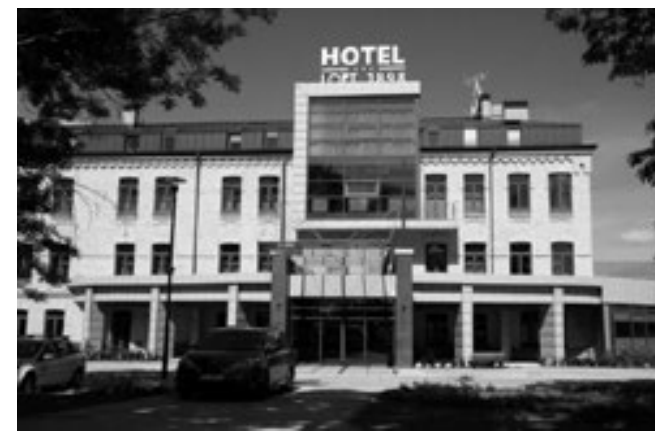

Ryc. 5. Hotel „Loft 1898” w Suwałkach budynek hotelu Źródło: A. Stankiewicz

Fig. 5. Hotel "Loft 1898" in Suwalki - hotel's building Source: A. Stankiewicz

W kompleksie Koszary Park w Olsztynie nowe funkcje wpisano w obiekty tak, aby w jak największym stopniu zachować czytelność historycznej przestrzeni urbanistycznej oraz formy architektonicznej. Podobne podejście charakteryzuje modernizację Białych Koszar w Ostródzie. Przykład Muzeum Armii Krajowej w Krakowie pokazuje, iż udana rewitalizacja zabytkowego obiektu, daje mu nowe życie i jednocześnie „przywraca” wartość historyczną zdegradowanemu obiektowi. Muzeum jest jednocześnie czytelnym eksponatem. Podobną rolę pełnią także Kotłownia, Areszt i Działownia - zrewaloryzowane obiekty Politechniki Krakowskiej, które $\mathrm{w}$ zachowanej lub zrekonstruowanej formie wraz z kontekstem zabytkowych obiektów uczelni przywołują historię miejsca - dawnych koszar Arcyksięcia Rudolfa.

\section{PODSUMOWANIE}

Modernizacje koszar są czytelne głównie w formie metamorfozy zabytkowych obiektów. Pierwsza prezentowana postawa projektowa, honorująca nadrzędną wartość historyczną, skutkuje subtelnymi interwencjami zharmonizowanymi z kontekstem dawnych kompleksów zabudowy. W drugiej grupie działań zabytkowe obiekty stają się materią przekształcaną. Często mamy do czynienia nawet ze spektakularną metamorfozą. Nowy obiekt, element czy detal kontrastuje $\mathrm{z}$ historycznym tłem, wyróżnia się i zwraca na siebie uwagę. W większości zaprezentowanych przykładów zachowano czytelność wartości historycznej obiektów. 


\section{PIŚMIENNICTWO}

Benevolo L., 1988. The history of the city, The MIT Press, Cambridge Massachusetts.

Bętkowski R., 2011. Dragoni z Olsztyna. Dzieje formacji i koszar, Imago Mundi, Olsztyn.

Bogdanowski J., 1996. Architektura obronna w krajobrazie Polski, Wydawnictwo Naukowe PWN, Warszawa-Kraków.

Holewiński M., 1996 Atlas Twierdzy Kraków. Koszary Arcyksięcia Rudolfa, seria I, tom 6, Kraków.

Holewiński M., 2000 Atlas Twierdzy Kraków. Koszary kawalerii w Kobierzynie, seria I, tom 6, Kraków.

Iwaniec M., 2013. „Białe Koszary” w Ostródzie, Renowacje i Zabytki 4, s. 148-152

Kalina T., 2014. Wojskowe nieruchomości zabytkowe znane i nieznane, Biuro Infrastruktury Specjalnej, Wojskowe Centrum Edukacji Obywatelskiej, Warszawa.

Kowalski T., 2013. W Sierpcu za cara. Śladami rosyjskiego garnizonu, Towarzystwo Przyjaciół Ziemi Sierpeckiej, Sierpc.

Król A., 1936. Budownictwo wojskowe 1918-1935. Historia, przepisy, zasady, normy., t. 1, Zakłady Drukarskie Galewski i Dau w Warszawie, Warszawa.

Krupiński A. B., 2000. Dziejei architektura tzw. Górnych Koszar obecnej siedziby Państwowej Wyższej Szkoty Zawodowej w Tarnowie, Tarnów.

Ostrowski W., 2001. Wprowadzenie do historii budowy miast. Ludzie i środowisko, OWPW Warszawa.

Paszkiewicz P., 1999. W stużbie Imperium Rosyjskiego 1721-1917, Instytut Sztuki PAN, Warszawa.

Podruczny G., 2013. Król i jego twierdze. Fryderyk Wielki i pruskie fortyfikacje stałe w latach 1740-1786, Napoleon V, Oświęcim 2013.

Podruczny G., 2011. Twierdza od wewnatrz. Budownictwo wojskowe na Ślasku w latach 1740-1806, Zabrze.

Rosolski S., 2014. City Park- tożsamość miejsca $w$ mieście $w$ aspekcie zagadnień odwrotnych, Zeszyty Naukowe Politechniki Poznańskiej. Architektura i Urbanistyka 31, s. 19-30.

Skrobot W., 2010. Historyczne zespoły pokoszarowe w Ostródzie, woj. warmińsko-mazurskie - rewitalizacja, zmiana funkcji czy rozbiór?, Kraków.

Urbaniak M., 2012. Leszczyńskie koszary z lat 1901-1905 na planach budowlanych Archiwum Państwowego w Lesznie, Leszno.

Wielgus K., Żaba T., Springwald R., 2013. Muzeum Armii Krajowej i Politechnika Krakowska-dobre sqsiedztwo: Ku czci żotnierzy Polski Podziemnej, Nasza Politechnika, 2, s. 3-8.

Wielgus K. i in., 2010. Koncepcja zagospodarowania terenu Politechniki Krakowskiej przy ulicy Warszawskiej - na Centrum Muzealno-Edukacyjne, maszynopis opisu koncepcji udostępniony przez autora, Kraków.

Wiraszka M., 2008. Rozwój przestrzenny i zabudowa miast Guberni Podolskiej w czasach Imperium Rosyjskiego, Neriton, Warszawa.

\section{ŹRÓDŁA INTERNETOWE}

trojmiasto.gazeta.pl/trojmiasto/1,35636,7151329,Artysci_chca_zamienic_dawne_koszary_w_sale_wystaw.html, dostęp: 3.04 .2015

www.bryla.pl/bryla/1,85301,17557888,Olsztyn_dawne_koszary_wojskowe, dostęp: 5.05.2015

http://ostroda.wm.pl/139308,50-organizacji-pozarzadowych-trafi-do-koszar.html\#axzz3dg5AnPfG, dostęp: 20.09.2015

http://www.renowacjeizabytki.pl/index.php?option=com_content\&view=article \&id=298\%3Aqbiae-koszaryq-w-ostrodzie\&catid=9\%3Aartykuy-techniczne\&Itemid=1, dostęp: 3.10 .2015

cdf.net.pl/modena-park-w-poznaniu.html, dostęp: 5.05.2015

http://leszektrebski.pl/?project=dawne-koszary-carskie, dostęp: 8.05.2014

http://www.pwsz.skierniewice.pl/plpl/galeria/campus/budynki.aspx, dostęp: 20.10.2015

\section{CONTEMPORARY MODERNIZATIONS OF HISTORICAL BARRACKS COMPLEXS - CHOSEN EXAMPLES REALISED IN POLAND}

Abstract: The article presents examples of last decades modernizations of historical Polish barracks complexes. There are presented historical ansambles, which military function was changed to a different one. Author tried to group the designer activities of architects: first inspired by historical context, when new object become to be a part of background and second, when new form is contrasted toward the background.

Key words:historical barracks, modernization, revaluation 